\title{
LIEDMAN JA ENGELSIN FILOSOFIA
}

metöitä tekevästä jumalasta. Useimmat mainitut fyysikot näyttävät uskovan "rationaaliseen maailmanjärjestykseen" (s. 203). On hyvä huomata, että tämäkin käsitys on idealistinen, vaikka se sulkeekin pois jumalan aktiivisen toiminnan. Materialistisen heijastusteorian mukaan "maailmanjärjestys" ei ole rationaalinen, vaan päinvastoin ihminen saa käytännöllisen toimintansa alan laajentuessa ration, so. järkensä, yhä paremmin heijastamaan tätä "järjestystä", ajatuksen liikkumaan yhä enemmän todellisuuden mukaisesti.

Laurikaisen uusi kirja osoittaa, kuinka ajankohtainen Leninin kirjoitus "Taistelevan materialismin merkityksestä" edelleen on. Materialististen luonnontieteilijöiden ja marxilaisten on yhdessä taisteltava tieteen hengen vastaisia taantumuksellisia katsomuksia levittäviä "pappishapatuksen diplomilakeijoita" vastaan. Tarvitaan $\mathrm{mm}$. enemmän todellista, asiallista tieteen kansantajuistamista. Toisaalta luonnontieteilijät itse tarvitsevat dialektista materialismia. Kuten Lenin mainitussa kirjoituksessaan toteaa, luonnontiede ei enää voi tulla toimeen ilman filosofisia johtopää töksiä. Luonnontieteilijän "luontainen materialismi", jota esim. Kari Lagerspetz esitteli artikkelissaan T \& E:n numerossa 4/77, ei aina riitä suojaamaan häntä tieteenvastaisilta idealistisilta johtopäätöksiltä eikä ollenkaan auta häntä käyttämään oikein sellaisia dialektiikan kategorioita kuin sattuma, välttämättömyys, laki, jatkuva, diskreetti jne. Suomalaistenkin luonnontieteilijöiden on laajasti, syvällisesti ja systemaattisesti tutustuttava dialektiseen materialismiin ja sosialistisissa maissa suoritettavaan laajaan luonnontieteen filosofisia ongelmia koskevaan tutkimustyöhön. "Fysiikka ja usko" sopii tällaisen opiskelun kimmokkeeksi kuin hikinen mies deodoranttimainokseen.
Sven-Eric Liedman: Motsatsernas spel. Friedrich Engels' filosofi och 1800-talets vetenskap $1-2$. Cavefors, Lund 1977.

Sven-Eric Liedmanin kaksiosainen tutkielma Engelsin filosofiasta ja sen yhteyksistä aikansa tieteeseen $(378+359$ sivua) ei tullut yllätyksenä. Liedman on esitellyt eräitä keskeisiä tuloksiaan jo aikaisemmin Häften för Kritiska Studierissa $(3 / 73,3 / 75$ sekä $5 / 76)$. Vaikka sen sisältöä siis saattoikin ennakoida, on myönnettävä sen olleen - ainakin minulle - pääosiltaan aikamoinen pettymys. Pettymys jopa huolimatta siitä, että ottaa huomioon Ruotsissa vallitsevan erikoislaatuisen aatteellisen ilmapiirin ja teoreettisen ajattelun heikonpuoleisen tason.

Liedmanin lehtijutut antoivat ennakoida tiettyä lähestymistä kohti sitä adekvaattisempaa marxisminäkemystä, jota HfKS eräässä viime vuoden numerossaan aika ennakkoluuloisesti nimitti "öststatsmarxismiksi". Tuohon ruotsalaisista hieman pelottavaan (sillä ainahan pikkuporvari aristelee kaiken proletaarisen edessä) "itämarxismiin" kuuluu olennaisena osana Engelsin luonnondialektiikan hyväksyminen. Siksi oli hauska nähdä, ettei Liedman kiertänyt näitä asioita, vaan yritti ja yrittää edelleenkin todella paneutua näihin "ontologisiksi" nimittämiinsä pulmiin.

Etsiskelyssään Liedman löytää ne samat todistuskappaleet joista kommunistinen liike on ollut tietoinen alun alkaen. Hän huomaa, että Marx on "Pääomassa" todennut määrän laaduksi muuttumisen lain pätevän sekä luonnontieteissä että historiassa (PO 1, suom., s. 282). Hän pääsee kirjeenvaihdon perusteella selville, että Marx on tehnyt "Anti-Dühringiä", yhteistyössä Engelsin kanssa, mikä luonnollisesti antaa aiheen olettaa Marxin myös hyväksyneen siinä esitetyt luonnondialektiset näkemykset. Tällaiset "corpora delicti" perustuvat välittömälle MEW:n tekstien lukemiselle ja ovat tietysti sinänsä melko triviaaleja. Merkittäväksi Liedmanin kannan tekee tässä tapauksessa se, että hän nostaa sen selväpiirteisesti Frankfurtin koulukunnan, nuoren Lukácsin (tulkitsijoineen) ym. "vasemmistolaisten" ryhmien näkemysten vastapainoksi. Viimeksi mainittujen ryhmien ajatuksen ydin voidaan nimittäin ilmaista toteamalla, että dialektiikkaa ei muka ole inhimillisen subjektin ulkopuolella (ts. dialektiikka ei heijastaisi objektiivista maailmaa). "Vanhan Engelsin" diskvalifioiminen tässä mielessä on samaa kuin ovien avaaminen marxismin subjektivistis-voluntaristisille tulkinnoille. Tällaisia tulkintoja esiintynee Ruotsissa huomattavasti enemmän kuin meillä; oli niin tai näin, niiden torjuminen on eräs Liedmanin kirjan myönteisistä pointseista.

Mutta (ja tämä on iso "mutta"!) Liedmanin koko lähtökohta-asetelma, hänen metodinsa, on omiaan turmelemaan hänen teoksensa myönteistä sisältöä. Hän tutkii Engelsiä aatehistoriallisen menetelmän avulla.

Saattaa olla, että ruotsalaisilla on enemmän syytä harrastaa aatehistoriallista tutkimusta kuin meillä. Kun seuraa jotain sellaista foorumia, jossa ruotsalainen yliopistovasemmisto esiintyy edes jossain määrin kokoontuneena, kuten esim. HfKS:ia tai vaikkapa Bokcafétin kirjaluetteloa, saa kuvan hämmentävän kirjavasta, "moniarvoisesta" teoreettisesta kaaoksesta, jossa pääpaino usein tuntuu olevan "keskustelussa" an und für sich, eikä, kuten marxismissa pitäisi, työväenluokan etujen adekvaattisessa ilmaisemisessa. Tällaisessa tilanteessa on varmasti lähellä ajatus, että pitäisi pyrkiä tuon aatteiden sillisalaatin objektiiviseen selvittämiseen, esimerkiksi juuri aatehistoriallisen metodin avulla.

Jotain tällaista lienee Liedmaninkin päässä liikkunut hänen 
suunnitellessaan kirjaansa. Hän toteaa itse: "Huvuduppgiften gäller rekonstruktionen av en tankevärld, en vetenskaplig miljö, ett ideologiskt och därmed samhälleligt kraftfält" (I, s. 18). Hän haluaa tällä tavalla saada selville sen, "mitä Engels todella sanoi". Lähestymismetodi herättää kuitenkin heti joukon kysymyksiä. Ennen kaikkea: saadaanko Engelsin luonnondialektiikan, tai yleisemmin, dialektis-materialistisen metodin ydin, sen "quinta essentia" esille tällä tavalla? Onhan niin, että marxismia ei voi jäännöksettömästi palauttaa tiettyyn aatemiljööseen. Tämän aatemiljöön tarjoama materiaali on aina enemmän tai vähemmän "sattumanvaraista", se ei kuvasta niinkään eri yhteiskunnallisten voimien pyrkimyksiä kuin sitä aatteiden pintatasoa johon nämä pyrkimykset vaatetetaan. Liedmanin metodi on periaatteessa sama, jota Reijo Wilenius on soveltanut kehnossa kirjassaan "Filosofia ja politiikka". Wilenius havaitsee, että Marx kytkeytyy "aristoteeliseen perinteeseen" ja selittää marxilaisuuden pois tällä tavalla. Häntä ei häiritse se, että myös marxismia vastustavat virtaukset nojaavat yhtä usein aristoteeliselle traditiolle.

Olen jo käsitellyt aatesuuntien definioinnin ongelmaa eräässä toisessa yhteydessä ("Marxismi-leninismin määrittelystä", Soihtu $1 / 78$ ), joten tyydyn nyt vain toteamaan, että Engelsin (ja Marxin, ja Leninin, ja koko kommunistisen työväenliikkeen) "aatemaailman" määritelmä ei nähdäkseni viime kädessä voi pohjautua muulle kuin sen toteamiselle, että se kuvastaa teorian, ajattelun tasolla adekvaattisella tavalla proletariaatin etuja. Kaikki porvarillisten teorioiden kritiikki - olivat nämä millaisia tahansa - lähtee loppujen lopuksi tästä liikkeelle. Aatteilla ei ole "itseliikuntaa", siksi maailmankatsomusten muotoutuminen ei selity pelkästään ajattelun tasolla pysyttäytymällä.

Pari esimerkkiä siitä, mitä tar- koitan. Osan II sivulla 112 Liedman väittää, että Engelsin ambitiona oli "att förena mekanisk materialism och dialektik". Liedman näkee siis asian sellaisena, että mekaaninen materialismi muodostaa yhden aatehistoriallisesti dokumentoitavan perinteen, dialektiikka toisen; kysymys on siis vain niiden yhdistämisestä - ja voilà: meillä on diamat. Edes se seikka, että kaava "mekaaninen materialismi + dialektiikka" on silmäänpistävästi contradictio in adiecto, ei näytä häiritsevän Liedmania. Kuitenkin kysymys saattoi Engelsin kannalta asettua vain seuraavasti: luonnontieteiden uusimpia saavutuksia on tarkasteltava työväenluokan maailmankatsomuksen kannalta, poliittisessa/yhteiskuntatieteellisessä analyysissa jo kyntensä näyttäneen dialektis-materialistisen metodin verifioitumisena myös luonnontieteiden piirissä. Tämä on jotain muuta kuin eri aatteiden "yhdistely".

Toinen, ja ehkä räikein, esimerkki Liedmanin aatehistoriallisen tarkastelutavan rajoittuneisuudesta on kirjan 14. luvussa. Siinä Liedman katsoo - yllättäen, sillä edeltäneet analyysit eivät ainakaan kyseiseen näkemykseen johdattele voivansa osoittaa Engelsin tuotannossa kolme eri "tendenssiä": yksi on "positivistinen", toinen hegeliläinen ja kolmas dialektismaterialistinen.

Tosin Liedman myöntää, että "bara en liten del av det Engels säger som kan ses som omedelbart uttryck för en av tendenserna" (sic!), mutta sittenkin hän luulee, että "det mångtydiga i Engels' arbeten bäst kan framställas om man ser dem som resultat inte av en utan av tre olika utgångspunkter" (II, s. 64). On ilmeistä. että nämä Liedmanin Engelsiltä löytämät kolme "tendenssiä" ovat myös sisällöllisesti jotain muuta kuin esimerkiksi ne marxilaisuuden kolme lähdettä ja perusosaa, joista Lenin aikoinaan pu- hui. Liedman puhuu nimittäin kolmesta eri m e t o d i tenuenssistä, kolmesta erilaisesta filosofisesta näkemyksestä, jotka jotenkin yhtyisivät Engelsillä. Lenin oli taas puhunut klassisesta politekonomiasta, utopistisesta sosialismista ja klassisesta saksalaisesta filosofiasta marxismille tarjoutuvana aikaisemman tieteen kehittämänä, sisäistettävänä "materiaalina", ei ulkokohtaisina, eklektisesti yhdistettävinä metodeina

Mitä Engelsin "positivismiin" tulee, näkee Liedman sen ennen kaikkea siinä, että dialektiikan lait näyttävät olevan "enormt omfattande empiriska generaliseringar, från vilka alla natur- och samhällsvetenskapliga lagar skulle kunna härledas" (II, s. 70). Olen sitä mieltä, että Liedman on tällä kertaa osunut eräälle marxilaisen ajattelun toistaiseksi selvittämättömälle läiskälle. Mitä oikeastaan olisi ymmärrettävä käsitteellä "dialektiikan laki'? On selvää, että laki määrän muuttumisesta laaduksi ei ole samassa mielessä "laki" kuin jokin fysiikan tai kemian lainmukaisuus. Ongelmaa on jonkin verran pohdiskeltu marxilaisessa kirjallisuudessa (vrt. esim. T. I. Oizerman kirjassaan "Probleme der Philosophie und der Philosophiegeschichte", Berlin/DDR 1972, s. 289: "Wie soll man . . die von der Philosophie des Marxismus erforschten allgemeinsten dialektischen Gesetzte der Bewegung, Veränderung, Entwicklung verstehen? ... Das sind sehr wichtige und komplizierte philosophische Fragen, und wir erheben keinen Anspruch, sie zu lösen").

Tämän arvostelun puitteissa ei tietenkään ole mahdollisuuksia ryhtyä sen pitemmälti puimaan "lain" käsitettä marxilaisessa filosofiassa jos kerran Oizermankaan ei paksussa teoksessaan rohkene paneutua siihen. Mutta tiettyihin yleisiin lähtökohtiin käy kyllä hyvin viittaaminen. Engels korosti "'Luonnon dialek- 
tiikassa", että "dialektiikan lait" formuloidaan, ei empiiristä tietä, vaan luonnon ja ihmisyhteiskunnan historiasta yleistäen. Ne eivät siis ole positivistisia yleistyksiä, vaan niiden yleistys perustuu sille, että ne ovat ihmisten esineellis-käytännöllisen toiminnan yleisimpiä tapoja, ja tällaisina taas puolestaan luonnon yleisimpien objektiivisten edellytysten determinoimia.

Se Liedmanin väite (tai ehkä kyseessä on vain kynän lipsahdus), että luonnon ja yhteiskunnan lait johdettaisiin dialektiikan kolmesta peruslaista, on ainakin minulle käsittämätön. Koskaan ei Marx "Pääomassa" tai muuallakaan perustellut sosialismin siirtymisen välttämättömyyttä vain abstraktisyleisesti kieltämisen kieltämisen lakiin vedoten. Samaa voidaan sanoa Engelsistä. Liedmanin väite on ristiriidassa myös hänen itsensä monasti - oikein - korostamansa Engelsin antireduktionismin kanssa. Eihän antireduktionismin idea liity ainoastaan materian eri liikemuotojen suhteellisen itsenäisyyden toteamiseen, siinä painotetaan myös pelkkien yleisten lakien alle tapahtuvan subsumoinnin riittämättömyyttä.

Liedman tekee II osan sivulla 168 mielenkiintoisen ekskursion sanan "ideologia" historiaan sellaisena kun se esiintyy Marxin ja Engelsin nuoruudentuotannossa. Alexander Jung oli erăs "Nuori Saksa"-ryhmän edustaja, josta Engels laati kielteisen arvostelun vuonna 1842 . Jung oli lanseerannut termin "ideologia" siinä mielessä, että se viittasi nimenomaan saksalaiseen idealismiin, ja Marx ja Engels ovat puolestaan poimineet termin merkitysyhteyksineen Jungilta "Saksalaisen ideologian" ingressiin. Tässä konkreettisessa asiayhteydessä, Liedman toteaa, käsite "ideologia" ilmaisee ennen kaikkea saksalaisen porvarin voimattomuuden tilaa: kun Englannin porvaristo alisti valtameret $\mathrm{ja}$ Intian hallintaansa, loi saksalainen porvari ideologioita.

Tämäntapaiset ekskursiot kuuluvat yleensäkin Liedmanin kirjan parhaimpaan antiin: ne pysyvät turvallisella, konkreettisella tasolla, jolla aatehistoriallinen menetelmä tosiaan "toimii" (ja saattaa olla niin, ettei aatehistoria voi koskaan muuta ollakaan kuin tällaista "bookworming"). Kohotessaan laajempiin yleistyksiin Liedman kuitenkin polttaa heti siipensä. Niin nyt "ideologia"-käsitteenkin kohdalla. Liedman on nimittäin saanut päähänsä (ks. I, s. 25 ja ed., II, s. 221 ja ed.), että Engelsin pitää, sen lisäksi että hän on "teoreetikko", olla myös "ideologi". Jopa niin, että "utan den ideologiska bestämningen är hela det företag, som Engels långt upp i medelåldern per sig in på (ts. "Luonnon dialektiikan" kirjoittaminen - V.O.), helt oförklarligt" (I, s. 25).

Ideologia on Liedmanille sama kuin "vetenskapens utomvetenskapliga användningsområde" (ks. I, ss. 23-24). Tässäkin on taas contradictio in adiecto. Miten "tieteen ulkopuolinen" alue enää voi pysyä tieteen ulkopuolisena, jos tiede kerran tuodaan sinne, jos sitä aletaan soveltaa siellä? Esimerkiksi työväenluokka on "neitseellisessä" tilassaan jotakin tieteen ulkopuolella olevaa, mutta se menettä̈ä toki tämän tilansa kun tieteellinen sosialismi tuodaan sen keskuuteen, yhdistetään työväenluokan jokapäiväiseen luokkataisteluun. Tieteen ja ideologian erottelu ajaa Liedmanin kohti aristokraattista tietoisuusteoriaa: tiede meită intelligenttejä varten, ideologia taas tyhmille duunareille. Itse asiassa kyse on vain vanhasta yläluokkalaisen vapaa-ajattelun mallista uusin etumerkein ("epäily sopii yläluokalle, rahvas tarvitsee uskontoa" -tyyliin).

Aristokraattinen tietoisuusteoria on niin syvässä, olemukseen saakka ulottuvassa ristiriidassa koko marxismin hengen, sen työväenluo- kan emansipaatioon tähtäävän ajattelun kannalta, että se ei voi jäädä Liedmaniltakaan huomaamatta. Siksi hän rupeaa etsimään tieteen ja ideologian "kosketuskohtia" (II, s. 223 ja ed.). Teksti käy näissä kohdin paikoitellen niin sekavaksi, että ajatuksenkulkua on vaikea seurata. Liedman yrittää selvitellä verkkojaan erottamalla (II, s. 178 ja ed.) "manifestin" ja "latentin" ideologian. Viimeksi mainittu tuntuu olevan yksinkertaisesti vain olemisen determinaatiota ajattelun ylitse.

Mille tällainen kahtiajako perustuu, sitä Liedman ei tyydyttävästi selvitä. Tuskin hän voisikaan. Liedmanin kirjan näitä sivuja lukiessa syntyy tietty epämiellyttävä tunne siitä, ettei enää olekaan tekemisissä minkään tutkielman, vaan pikemminkin jonkinlaisen patologisen dokumentin kanssa. Näin siksi, että Liedmanin teos on mielestäni huomattavasti enemmän sen kirjaanpano, kuinka vaikeata porvarillisista lähtökohdista kohoavan sivistyneistön edustajan on omaksua marxismin keskeistä aatesisältöä, kuin mikään vakavasti otettava tutkimus Engelsin luonnondialektiikasta.

Voidaan todeta, että "Motsatsernas spel"'-teos hämää paksuudelaan. Reaalista informaatiota marxilaisen filosofian ja luonnontieteiden suhteista siinä ei juuri ole, ja tässä mielessä se muistuttaa tavallaan Liedmanin maanmiehen Olaus Rudbeckin "Atlanticaa". Jos Rudbeckin hurjat visiot kuvastivat aikansa ruotsalaisen sivistyneistön henkistä ahdinkoa ja sekavuutta suurvaltaseikkailujen aikana, niin "Motsatsernas spel" taas vuorostaan heijastaa sitä ruotsalaisen vasemmistosivistyneistön surullista teoreettista jälkijättöisyyttä, josta mainitsin jo tämän juttuni alussa.

Eräs, ei vain Liedmanille, vaan yleensä ruotsalaisille symptomaattinen piirre on Neuvostoliitossa ja muissa sosialistisissa maissa suoritetun tutkimuksen lähes täydelli- 
nen ignorointi. Pelkästään marxilaisen filosofian ja luonnontieteiden suhteita käsittelevää kirjallisuutta ilmestyy NL:ssa vuosittain useina kymmeninä teoksina. Ja esim. B. M. Kedrovin laajasta Engelsiä käsittelevästä tuotannosta Liedman tuntee vain yhden teoksen.

Koska Liedman on sitä mieltä, että "marxismen i Sovjet och Östeuropa kan fortfarande sammanfattas i Osnovy marksizmaleninizma, $i$ en handbok $i$ marxism-leninismens grunder", ei sosialistisissa maissa harjoitettu tutkimus edes periaatteessa näytä voivan kiinnostaa häntä. On vain luonnollista, että tällainen suhtautuminen kostautuu. Vaaralliseksi asia muuttuu vasta kun tätä ei huomata tai edes haluta huomata.

Vesa Oittinen
Viime numeron tieteellisessä elämässä post festum-uutisena mainittu TIEDE-TAIDE-IHMINENTAPAHTUMA, joka pidettiin 11.-12. 2. Neuvostoliiton kulttuuri- ja tiedekeskuksessa onnistui erinomaisesti. Tuskin kukaan yli kolmesta sadasta osanottajasta on tässä suhteessa toisin ajatteleva.

Tapahtuman kahtena keskeisenä teemana - niin yleiskeskustelussa, työryhmissä kuin loppupanelissakin - oli yhtäältä tieteellisen ja taiteellisen haltuunoton välinen suhde ja toisaalta humanismi tänään. Molempien teemojen käsittely jäi tosin alustavaksi mutta samalla hedelmällisesti keskeneräiseksi. Paine jatkon kehittämiseksi tälle taide \& tiedeväen sekä muun kulttuurikansan tapaamiselle jäi tuntuvaksi.

Ensiksi mainittua teemaa käsitteli tieteenhistorioitsija ja mainio tieteen popularisoija tohtori Henrik Volkov. Hän puhui erityisesti taiteen maailman vaikutuksesta tieteen tekoon. Seminaarissa kukaan ei ottanut esille asian toista puolta, nimittäin tieteen maailman (tieteellis-teknisen kumouksen jne.) vaikutusta taiteen maailmaan. Toisaalta on ymmärrettävää että Volkov tieteen tuntijana pitäytyi omalla maaperällään.

Vähemmän ymmärrettävää oli se, että työryhmät näyttivät eriytyvän yhtäältä tutkijoiden ja toisaalta taiteilijoiden ryhmiksi. Ainakaan elämäntapa-tutkimuksen ryhmään ei tainnut ilmaantua yhtään taiteilijaa. Tokkopa taiteilijoita oli ollut myöskään työn inhimillistämistä pohtineessa ryhmässä. Toisaalta tutkijat karttoivat esteettisen kasvatuksen ryhmää ja tiedottajien ryhmässå taisi olla 'käsitteen mukaisesti' pelkästään tiedotuksen ammattiväkeä. Loppuraporteista päätellen kaikki ryhmät olivat kyllä tyytyväisiä tuloksiinsa. Mutta perustellusti voisi työryhmätyőskentelyä koskevan yleishuomion kuitenkin vastaisuuden varalle formuloida kehoitukseksi: enemmän työtä tieteen ja taiteen dialogin edellytysten luomiseksi.

Toiseen teemaan eli humanismiin johdatteli professori Juha Manninen. Hän analysoi nousevan porvariston humanismia, jota. luonnehti suuret järjen ja vapauden prinsiipit, ja vertasi sitä vakiintuneen ja imperialistisen kapitalismin porvarilliseen rappiohumanismiin. Tämän teeman käsittely jäi sikäli kesken että marxismin ja humanismin välinen suhde jäi analysoimatta. Mannisenkin esityksessä tämä "ylittämis"-problematiikka (Aufhebung) jäi vain muutamaan sanaan esityksen lopussa.

Kesken jääneen, mutta hyvän sysäyksen saaneen humanismiteeman käsittely on erityisen tärkeä siksi, että edistyksellisen - jopa marxilaisen - sivistyneistön keskuuteen on levinnyt mitä kummallisinta "humanismia". Kapitalismin kulttuuribarbarian aikana ei ole tietenkään outoa, että syntyy kapitalismi-kritiikki, jossa perustana on käsitys (ylihistoriallisesta) tosi ihmisolemuksesta. Ihanne ja todellisuus asetetaan vastakkain, mutta mitä tästä seuraa: tuloksena on impotenttia kritiikkiä, jolla ei saa otetta kapitalismiin. Tämä impotenssi koskee yleisemmin kritiikkiä, joka ottaa mittapuuksi käyttöarvon - oli tämä käyttöarvo sitten tosi ihmisolemus, tuotantovoimat tai idyllinen maalaisyhteisö. Tuloksena on vain moralisointeja. Sen sijaan olisi keskusteltava marxilaisesta kapitalismikritiikistä niin tieteessä kuin taiteessakin. Näin ehkä seuraavassa tapaamisessa. . .

TUTKIJALIITON YHTEISKUNTATIETEEN ALAN JAOSTO JÄRJESTI VALTAKUNNALLISEN SIVISTYNEISTÖSEMINAA-

RIN 8. 4. - 78 Helsingissä. Tarkoituksena oli analysoida ja käydä keskustelua lukeneiston asemasta yleensä ja erityisesti Suomessa. Asiaa valoitettiinkin varsin monelta kantilta ja varsin kulttuuripitoisesti. Kokoavat ja suuren linjan ko- 